\title{
Pedogenesis, Pedochemistry and the Functional Structure of the Waldhufendorf Field System of the Deserted Medieval Village Spindelbach, the Czech Republic
}

\author{
Jan Horák ${ }^{\mathrm{a}, \mathrm{b}^{*}}$, Tomáš Klír ${ }^{\mathrm{a}}$ \\ anstitute of Archaeology, Faculty of Arts, Charles University, Celetná 20, 11636 Prague 1, Czech Republic \\ ${ }^{b}$ Department of Ecology, Faculty of Environmental Sciences, Czech University of Life Sciences, Kamýcká 129, 16521 Prague 6 - Suchdol, Czech Republic
}

\section{ARTICLE INFO}

\section{Article history:}

Received: $15^{\text {th }}$ December 2016

Accepted: $5^{\text {th }}$ May 2017

DOI: http://dx.doi.org/ 10.24916/iansa.2017.1.4

Key words:

Medieval colonisation

Medieval-Modern Era transition

village economy

field system ecology

podzol

multi-element analysis

phosphorus

\begin{abstract}
$A B S T R A C T$
Spindelbach was a Waldhufendorf type of village, i.e. every household could manage its own fields independently of other households. Our study has importance for research on the economic and social development between the Medieval and Modern Era and for studies of human impact. Performing soil and geochemical mapping, we have identified four geochemical factors in a clearly interpretable pattern: 1) general geology and soil environment (represented mainly by Al, Si, K, Ti, Rb, Sr and $\mathrm{Zr}$ ) contrasting with the soil organic matter and with pollution coming from atmospheric deposition $(\mathrm{P}, \mathrm{As}, \mathrm{Pb}$ and $\mathrm{LE}$ - elements from $\mathrm{H}$ to $\mathrm{Na}$ ); 2) modern pollution and possible historical human activity (mainly $\mathrm{As}$ and $\mathrm{Pb}$ vs $\mathrm{Zn}, \mathrm{Fe}$ and $\mathrm{Mn}$ ); 3) historical human activity related to the village ( $\mathrm{Zn}$ and $\mathrm{Sr}$ ); and 4) additional historical human activity of another spatial pattern (P). Although there was no unambiguous relation between podzolization and the human activities observed, generally podzol development was very rapid (it was positively observed on sites ploughed ca 600 years ago). Differences among the households' agricultural managements were observed; these could be based on: 1) types of land use in the village area; 2) management intensity; and 3) the subjective management preferences of the peasants. The differences were manifested by their intensity and by their spatial distribution.
\end{abstract}

\section{Introduction}

Agricultural field systems have been heavily studied in the central European area (e.g. Klír 2008; 2016; Kötschke 1953; Krenzlin 1952; Krüger 1967; Lienau, Uhlig 1978). The main points of these studies were the villages identification and mapping in their terrain and the classification of the villages based on their field systems. Other studies have been performed in Britain and elsewhere, generally in the northwestern and northern parts of Europe (Frandsen 1983; Hall 2014; Christie, Stamper, Eds. 2012). These field systems bear crucial information: not only about the agricultural practice of rural societies, but also about the fundamental agrarian, social, and environmental changes in Europe over the last millennium (Hoffmann 2014; Klír 2010a; 2010b; Schreg 2013). That is to say, in European agrarian society, field systems have reflected the socio-economic organisation

*Corresponding author. E-mail: jan_horak@email.cz
- and every field pattern has been intrinsically connected with the specific economic and social relations, as well as the agricultural practice (Hopcroft 1999, 15; De Moor et al. 2002; Thoen 2004). The spatial distribution of agricultural activities can also provide information about the "pure culture" (Jones 2009).

The relationship between human settlement activities and the soil part of the biosphere has been intensively studied over the decades. Such intense study has introduced a wide spectrum of topics: the influence of soils on the placement of human activities in the landscape; the interaction between human activities and their soils; soils as one of the basic archives of archaeological evidence; and also the role of human activity as a factor in the pedogenic direction (Bork et al. 1998; Walkington 2010). Nevertheless, there are also stimuli for more multi-disciplinary research, as many projects are still focused on either the historical or natural perspective, without bringing them together. For example, Rainer Schreg writes about the need to use an ecological 
approach in landscape archaeology, where traditional approaches usually only aim at the reconstruction of the environment (Schreg 2014). We see the question from the other side: an insufficient integration of archaeological and palaeoenvironmental methods with purely historic themes, as well as with historical periods (at least in the centralEuropean context where environmental archaeology prevails in the research of prehistoric times).

Soils on archaeological sites are studied in many ways: macroscopically (Kristiansen 2001), micromorphologically, and geochemically. Some studies are focused on using phosphorus (see Holliday, Gartner 2007), and there are also studies using multi-element analyses. These analyses are mostly focused on the differentiation among basic archaeological features (houses, fields, hearths and so on), on the verification of human activities, and also on the analysis of the spatial distribution of these activities (Davidson et al. 2007; Nielsen, Kristiansen 2014; Roos, Nolan 2012; Wilson et al. 2009). The spatial extent of particular activities (e.g. manuring) or land-use types (arable fields, pastures, meadows, or gardens) has also been studied (Entwistle et al. 1998; 2000; Salisbury 2013).

Our research of Spindelbach is part of a series of projects focused on the medieval settlement and its transition into the Modern Era (summary by Klír 2010a; 2010b). Thematically, it belongs to the interest of European archaeology in the Medieval-Modern Era transition and the processes of social structure development, regional diversity, and economic history (Andersson et al. 2007; Cerman 2002; Cerman, Maur 2000; Petráň 1964; Scholkmann et al. 2009). The archaeological context of the Czech research into the Medieval settlement is relatively rich (Klír 2008; Krajíc 1983; Nováček 1995; Smetánka 1988; Smetánka, Klápště 1981; Smetánka et al. 1979; Vařeka et al. 2006). However, the majority of this research has avoided mountainous areas, where a combination of traditional agricultural subsistence with non-agricultural production took place (Klír 2010a; 2010b).

We have chosen the village of Spindelbach for the following reasons: 1) its location in a mountainous area (on a ridge); 2) the preservation of at least part of its field system terraces, enabling the identification of fields belonging to particular households; 3) it being a Waldhufendorf type of village, i.e. an economic system where every household could manage its fields completely independently of other households; 4) the presence of other historical activities unrelated to the village, but possibly influencing geochemical and soil conditions - charcoal-burning sites and glassworks; 5) the possible presence of non-agrarian activities - iron processing - revealed by a previous reconnaissance of the site; and 6) previously-observed podzolization gradients enabling the study of its relation to human activities.

Our aims were: 1) to perform detailed soil and geochemical mapping with respect to property ownership; 2) to identify geochemical tracers (i.e. geochemical bearers of information) of past human activity (e.g. phosphorus is the tracer mostly used); 3) to perform analyses and assess the

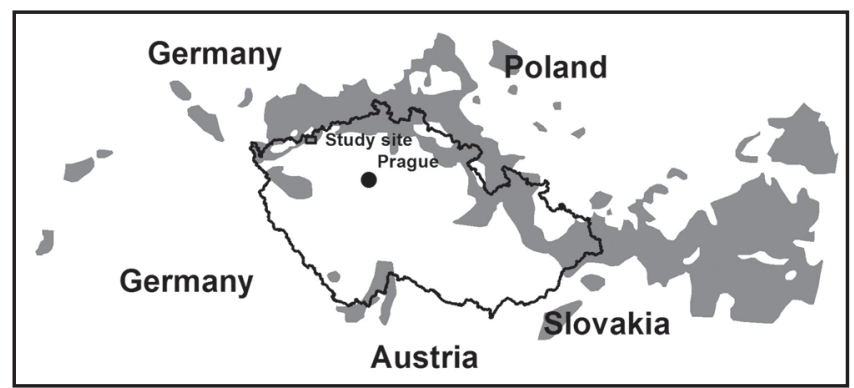

Figure 1. Location of the study area in the Czech Republic near the Czech-German border. Grey areas indicate the spatial distribution of "Waldhufendorf" field system type in central Europe (by Schröder, Schwarz 1969: map "Die ländlichen Ortsformen in Mitteleuropa gegen Ende des Mittelalters").

spatial distribution of these tracers; 4) to evaluate possible differences among parcel strips (i.e. householder ownership) and also within the parcel strips, and thus find possible management intensities and attitudes among householders; and 5) to find and identify the possible relation between podzolization and human activity.

\section{Materials and methods}

\subsection{Study site}

The deserted Medieval village Spindelbach was located on a ridge of the Krušné Hory (Ore Mountains, Erzgebirge) in north-western Bohemia, ca $3 \mathrm{~km} \mathrm{NW}$ from the small town of Výsluní, close to the Czech / German border $\left(50^{\circ} 28^{\prime} 52.995^{\prime \prime} \mathrm{N}, 13^{\circ} 11^{\prime} 42.143^{\prime \prime} \mathrm{E}\right)$ - see Figure 1.

The site (Figure 2 and Figure 2.1 in Supplementary Online Material - SOM) consists of a built-up area along the Prunéřovský stream (originally called Spindelbach) and the fields coming from it in the form of parcel strips aligned in a south-west to north-east direction (research into which is presented in this study). The main system of probes and places in the area of the researched field system is based on the system of parcel strips numbered upwards with altitude, and distance, meaning the distance from households (since the main field pattern is a linear one from households). The term "distance" always means the distance from the households in the direction of the strips - in the text, on plots, in figures and in tables. The terms used for spatial descriptions are also related to distance from households: "village vicinity" being the area of fields up to a distance of ca $350 \mathrm{~m}$, and the term "distant part" marks the area of fields between a distance of 950 to $1750 \mathrm{~m}$. The "background area" marks the area around the background probes 100001 to 100005 . The term "high altitude area" means the area above the last $\left(13^{\text {th }}\right)$ strip, which includes the background area. There are also other historical landscape features such as: charcoal burning sites (almost all over the researched area up to the distance of $750 \mathrm{~m}$ ); agrarian stone heaps/mounds found only in the area of strips no. 8 to 12 to the maximum distance of $350 \mathrm{~m}$; and glassworks (built-up area at the altitude of strip no. 10 and at 
Figure 2. The examined part of the field system. The Prunéřovský stream is located in the built-up area at the left edge of the figure. Houses are located only along this stream. The depicted altitude ranges between ca 800 and $915 \mathrm{~m}$ above sea level. The probes in fields are marked by crosses, the background probes are located in the highest areas and are marked by stars and by numbers 100001 to 100005 . Agrarian stone heaps are located mainly in the western corner of the studied area (ca strips 8 to 12 , distances 50 to $350 \mathrm{~m}$ ). Glassworks are located in the built-up area (against strip 10) and in the fields (strip 4, distance $750 \mathrm{~m}$ ). For a colour version, see Figure 2.1 in SOM.

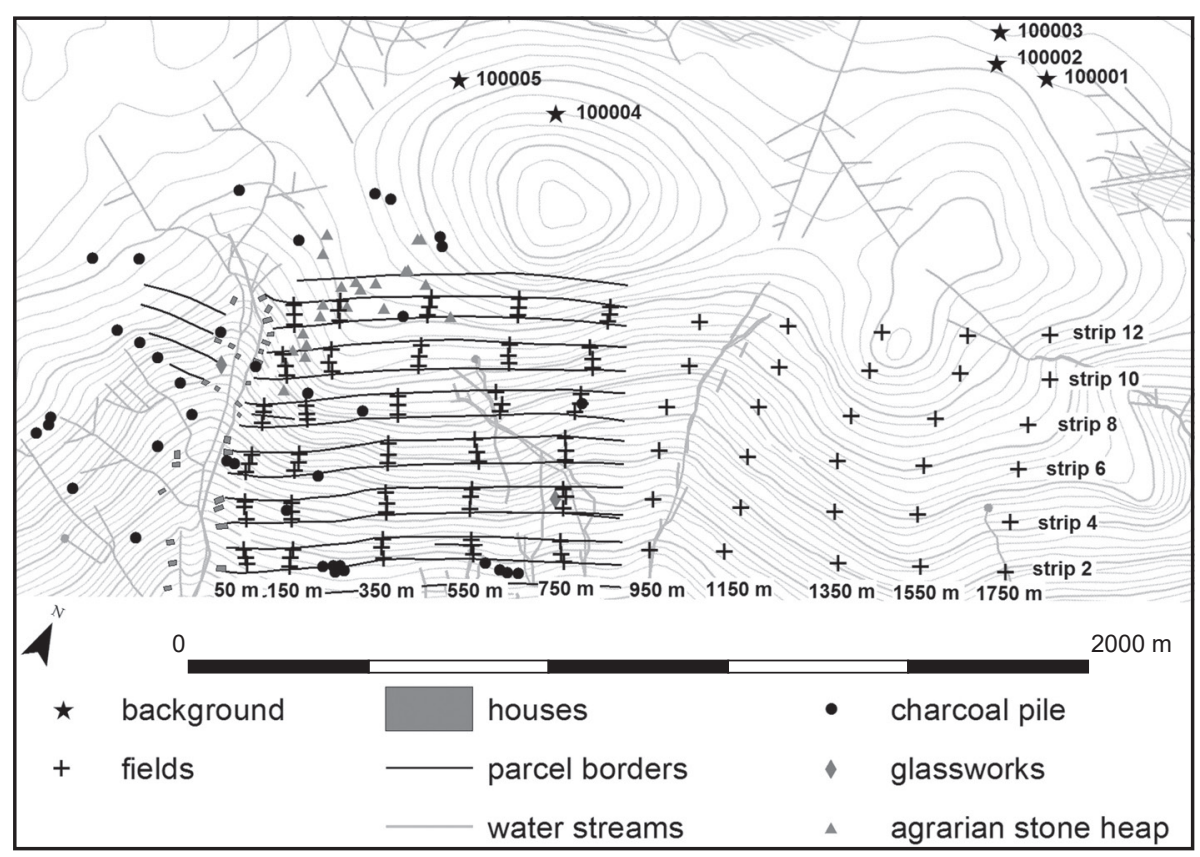

strip no. 4, at the distance of $750 \mathrm{~m}$ ). There were 13 parcel strips identified, mainly on the basis of LIDAR data and fieldwork observation. There was a place for one or two possible parcel strips more, but it was impossible to decide their possible presence clearly due to the lack of any terrain marks or LIDAR data (the terrain there was merely flat). At higher altitudes, it was mainly peat bog terrain and thus we did not presume any parcel strips there.

\subsection{History of the village}

The village came into existence in the $13^{\text {th }}$ century (probably in the second half, see Crkal, Černá 2009). There were also three glassworks in the area chronologically preceding the village's existence with no clear functional connection to the village; there was probably some chronological hiatus between them. There are toponyms like "Glassberg" in Medieval-written sources, but with no notes about the glassworks themselves. It is therefore probable that the glassworks were abandoned by the time of the village's foundation (Crkal, Černá 2009). The glassworks were located in the area of later village fields (strip 4, distance $750 \mathrm{~m}$ ) and in the built up area at the altitude of strip 10 (Figure 2 and Figure 2.1 in SOM). There was also a third glassworks in the south-western part of the village vicinity. The first written record concerning the village comes from 1356 (RBM VI, 175 No. 329; written as "Spinnelbach"), when it belonged to the Alamsdorf family. The last written source comes from 1481, when half of the village was sold (Profous 1951, 552; Sedláček 1923, 59). The Hasištejn dominion property, to which Spindelbach belonged at that time, was divided in 1490 and there was a note about Spindelbach in the division document, but only of Spindelbach as a forest and a fishpond, not a village (AČ V, 543). Therefore, it is presumed that the village had been abandoned sometime between 1481 and 1490. The toponym "Spindelbach" and its variants marking forests, fishponds, or meadows, were noted in written sources from the $16^{\text {th }}$ and $17^{\text {th }}$ centuries; it can also be found on the first military mapping of the area from 1767, or on the stabile cadastre map from 1842 (Crkal, Černá 2009; Figures 13.6.1 to 13.6.5 in SOM).

Spindelbach was a typical "Waldhufendorf" (or "Gelängeflur" - e.g. Klír 2008, 158) village. We base this statement on these indications: 1) it was a typical village system in this region; 2) the preserved parcel strips system in the form of terraces was fairly regular and the strips were spatially connected to the individual households; and 3) our team is experienced in researching such villages and their field systems (e.g. Klír 2008; 2010a; 2010b; 2013; Klír, Kenzler 2009). Waldhufendorf was a regular field system in central Europe, which was developed during the reclamation of woodland along middle to high altitude mountains during the High Middle Ages, i.e. from the $11^{\text {th }}$ to the $14^{\text {th }}$ century (Krüger 1967; see Figure 1 - grey areas). This field system consisted of wide, long strips, almost equal in size to that of each farmstead, ideally ca $100 \mathrm{~m} \times 2300 \mathrm{~m}$ (Kuhn 1973; Krüger 1967, 109-110; see Figure 3). Spindelbach parcel strips were only about 50 to $55 \mathrm{~m}$ wide. The peasant farmstead lay at the head of the strip. Slightly curved, the strips were adapted to the topography. It is important to mention that the agrarian system was individualistic rather than communal. This means that each farmstead could make its own economic decisions regarding their cultivation independently, because each strip was easily accessible as a consequence of its compact position within the landholding (Lienau, Uhlig 1978, 216; Krüger 1967; Hopcroft 1999, 22-24). In the Modern Period, the original field pattern was usually disrupted and the strips subdivided as a consequence of socio-economic differentiation (e.g. Born 1977, 167-170). 


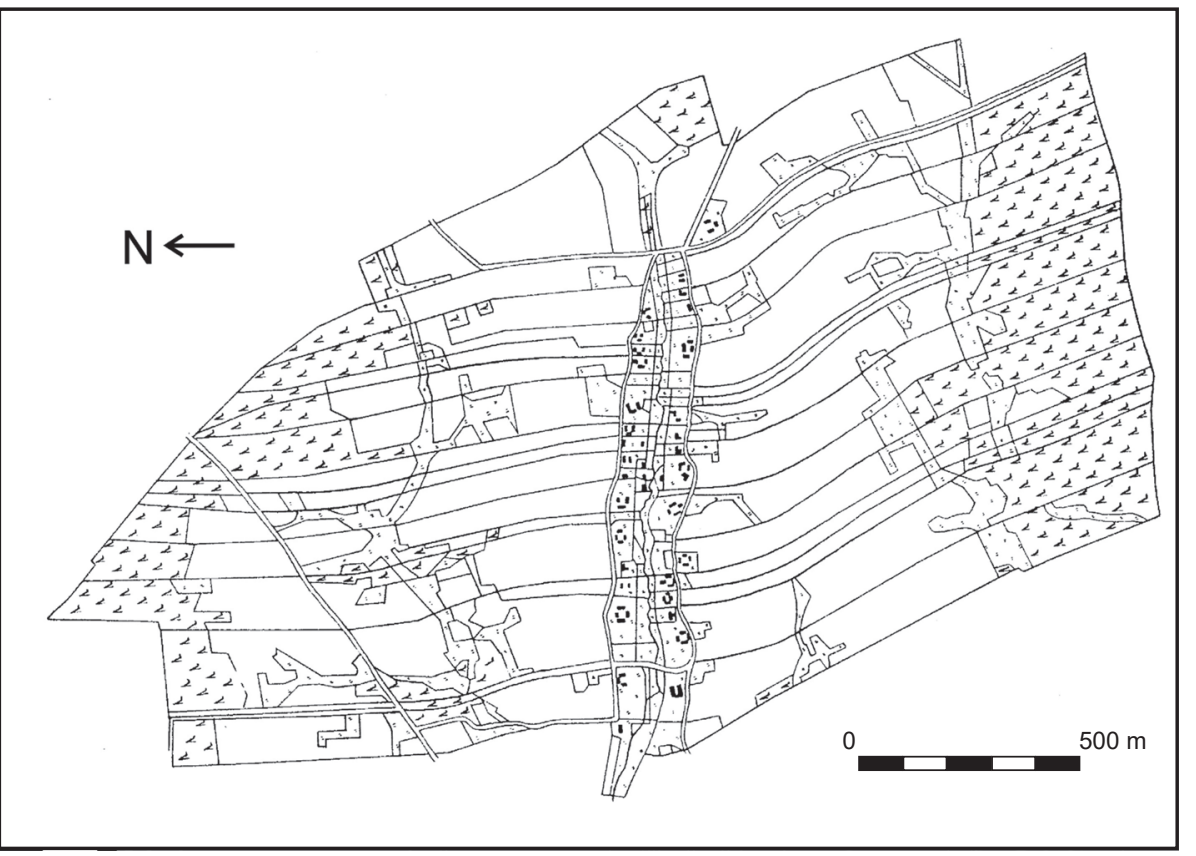

Figure 3. A typical field system of Waldhufendorf: Röllingshain (Saxony, Germany, by Kötschke 1953: Figure 27). Note boundaries between households and their parcel strips. Every household has its own parcel strip, which can be managed independently of other parcel strips. The picture displays usual the pattern of landuse types: fields and forests at the ends of parcels. Such detailed ground plans are available only for villages still existing in Modern Era mapping, and not for villages abandoned in the Medieval Era.

\subsection{Environment}

The village was located on a gentle southern slope, just under a ridge of the Ore Mountains, at an altitude of ca 700 to $900 \mathrm{~m}$ asl (researched area ca 800 to $900 \mathrm{~m}$ asl). The built-up area was situated along a little stream (Prunéřovský potok) - see Figure 2. The average annual air temperature is between 4 and $6^{\circ} \mathrm{C}$, and the average annual sum of precipitation is between 800 and $1000 \mathrm{~mm}$ (Tolasz et al. 2007). The geological bedrock is mostly made of Palaeozoic and Proterozoic orthogneisses and paragneisses (Figure 13.2 in SOM). In the surroundings of water streams, thick fluvial and colluvial sediments of weathered material can be found.

The soil cover appears to be made of cambic podzols (according to Czech map sources - see Figure 13.4 in SOM), which corresponds to haplic podzols by the World Reference Base for Soil Resources taxonomy (WRB), or to spodosols by the US Soil Taxonomy (USDA). This soil appears to be distributed homogeneously over the whole study area.
Only the flat, highest areas with peat bogs are covered by organic soils - histosols. Our detailed sampling enabled the observation of gradients of soil types between cambisols to podzols (cambisols to haplic and entic podzols by WRB, or inceptisols to spodosols by USDA). Cambisols are the soils characterised mainly by intrasoil weathering reaching into the yellowish, reddish and brownish B horizon. Sometimes, this B horizon can be more coloured in its upper part (higher chroma in Munsell system). Podzols are soils originating mainly in mountainous regions with a humid climate, coniferous vegetation cover, and an acid $\mathrm{pH}$, leading to the leaching of clay minerals, organic matter, cations, and so on downward through the profile. As a result, a greyish to white "eluvial" E horizon can be observed beneath the organicmineral A horizon. The transported matter is accumulated in the B horizon, leading to its stronger colouring in reddish and brownish colours. The schematic sequence of the horizons can be seen in Table 1, and examples of the studied

Table 1. Schematic description of soil horizons and their labels used in this study. Table features: * O, A, E, B and C are used among majority of description systems, though detailed descriptions can vary; ** these labels are used only in this study for purposes of statistical analyses and visualisation, BD stands for B Darker facies; *** data from these horizons are not presented in the paper; cm represents where the horizon was measured: A and $\mathrm{E}$ in every $1^{\text {st }}$ and $3^{\text {rd }}$ $\mathrm{cm}$ of that horizon, BD and B30 in every $2^{\text {nd }}$ and $7^{\text {th }} \mathrm{cm}$; also depths 30 and $40 \mathrm{~cm}$ were measured irrespectively of the horizon; $\dagger$ measured irregularly only in few cases; See also figures 13.5.1 to 13.5.8. in SOM.

\begin{tabular}{ccccl}
\hline Cambisols* & Podzols* & Labels Used $* *$ & cm & Description \\
\hline O & O & $* * *$ & 0 & Organic, not fully decomposed matter on the surface \\
A & A & A & $1 ., 3$. & Dark, almost black organic-mineral horizon \\
$n o E$ & E & $* * *$ & $1 ., 3$. & Eluvial, grey to white horizon, leaching zone \\
B & B & BD & $2 ., 7$. & Darker facies of B horizon, accumulation zone \\
B & B & B30 & $2 ., 7 ., 30$ & B horizon, also accumulation zone, to 30 cm \\
B & B & B31-40 & 40 & B horizon in depths 31 to 40 cm \\
B & B & $* * *$ & $\dagger$ & B horizon deeper than $40 \mathrm{~cm}$ \\
C & C & $* * *$ & C horizon - weathered bedrock, parent substrate
\end{tabular}



observed presence of podzolization in all probes to visualize the heterogeneity of soils in the study area. It also shows the sampling pattern / grid in its ideal form. Note three lines of sampling at distances 50 to $750 \mathrm{~m}$. Grey rectangles indicate probes where no $\mathrm{E}$ horizon (i.e. macroscopicallymanifested podzolization) was observed. White rectangles indicate the presence of $\mathrm{E}$ horizon. For another visualization (E horizon thickness) see Figure 4.1 in SOM.
Figure 4. The scheme represents the

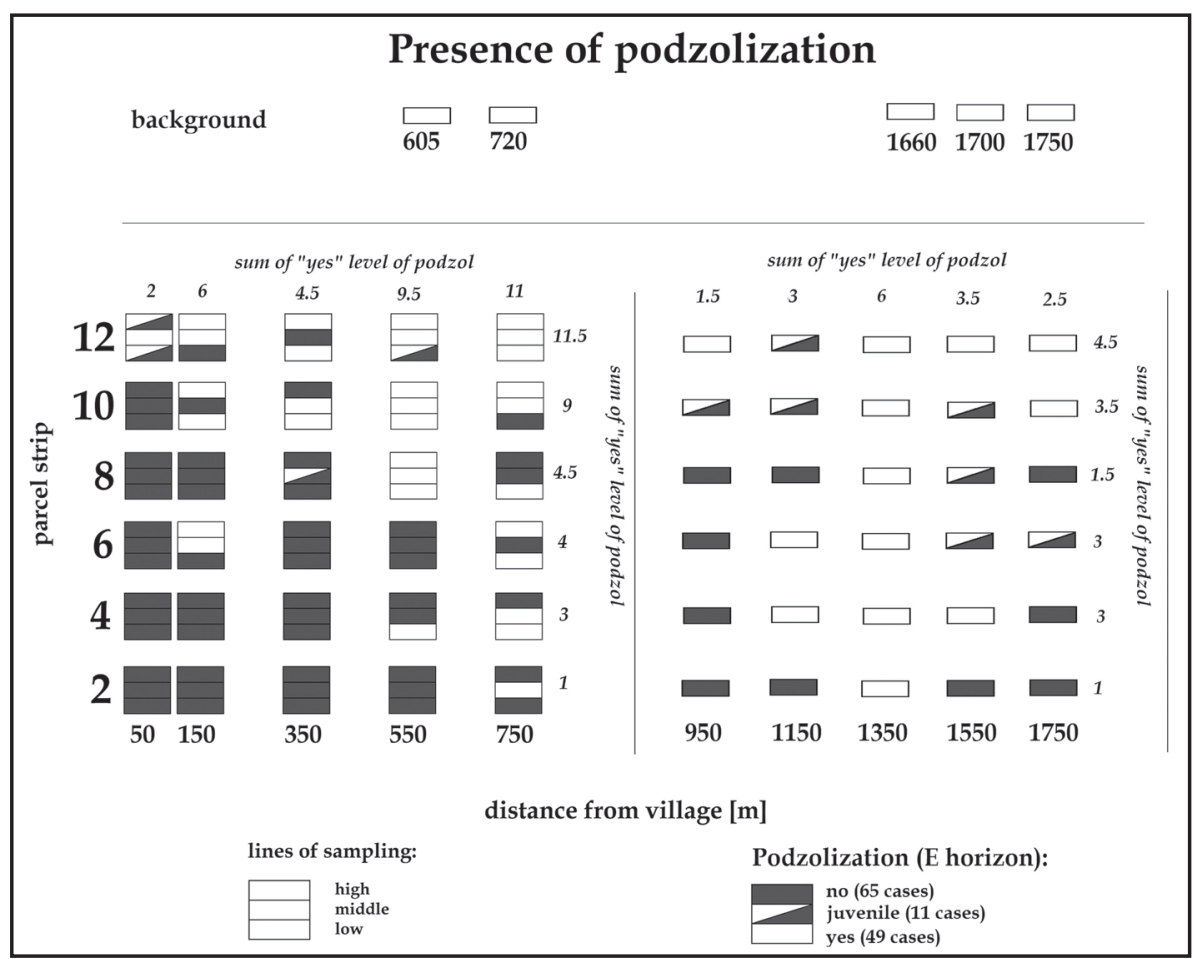

profiles, including horizon descriptions, can also be seen in Figures 13.5.1 to 13.5.8 in SOM. The soil matter was made mainly of silt and sand material. Gravel-like and stone material could be found mainly at depths of $40 \mathrm{~cm}$ and deeper. It was also observed at depths of around $20 \mathrm{~cm}$ in strips no. 10 and 12 . We have also found large boulders in the probes, but only in a few cases (strip no. 12, at distances of 150 and $550 \mathrm{~m}$, and strip no. 4 , at $750 \mathrm{~m}$ ). We have usually found the transition between the $\mathrm{B}$ and $\mathrm{C}$ horizons to be at depths around 50 to $60 \mathrm{~cm}$; no firm bedrock was found in the probes. We have found varieties of soil types on a gradient going from cambisols to podzols. As a basic deterministic characteristic of the position of the soil on this gradient, we used the distinguishing of the presence of the E horizon, with the possibilities: "no" i.e. the soil type was cambisol; "yes" i.e. the soil type was a podzol; and "juvenile" - there was observed some slight indication of eluviation juvenile stages of E horizon. The schematic mapping of the distribution of these categories is presented in Figure 4. From a comparison of Figure 4 and an output from the official Czech pedological mapping (Figure 13.4 in SOM), it can be seen that merely mapping is unsuitable for any detailed archaeological work and interpretation. We also performed an interpolation of thickness of the E horizon, which could be used as proxy information for the rate of podzolization (see Figure 4.1 in SOM).

The hydrology is represented by numerous streams, three of which are permanent in character: 1) the Prunéřovský stream in the built up area; 2) unnamed streams at distances of 550 to $750 \mathrm{~m} ; 3$ ) a stream along the probes at a distance of $950 \mathrm{~m}$. Other streams of the researched field system area are intermittent in character. There are peat bogs at the highest altitudes in an area behind the ridge (along the upper edge of Figure 2).

\subsection{After desertion - land use, land cover, pollution and modern forest management}

It was mentioned that the toponym Spindelbach was related mainly to the forests and meadows after the village desertion. The name was also related to the stream (Figures 13.6.1. to 13.6.5 in SOM). The meadows were located only in the area of the previously built-up area, and the village fields were covered by forests. Sometime in the course of the Modern Era, there was some charcoal burning activity performed in the area (see location of charcoal burning sites in Figure 2 and in Figure 2.1 in SOM). This activity probably did not chronologically relate to the village existence due to its collision with the village agriculture. There were also probably unusable forests during the time of the village. We interpret this activity as related to mining and ore processing, which started in this area during the $16^{\text {th }}$ century (the town Výsluní was originally a mining town). Modern forest management focuses on the growing of spruce (Picea sp.) and larch (Larix sp.); birch trees (Betula sp.) can also be found in the area. During the 1970s and 1980s, there was important ecological damage made to the Ore Mountains vegetation as a result of acid $\mathrm{SO}_{\mathrm{x}}$ and $\mathrm{NO}_{\mathrm{x}}$ rains (chemicals coming from the industrial area in north-western Bohemia). This was followed by an invasive action of forest management, based on bulldozering the soils into mounds (after damaged timber mining) and on the spreading out of these mounds several years later. This action damaged and mixed the original soil profiles. The areas managed in this way can be found in the south-western parts of the village field system, in the highest areas, and also in the study area at the distances of 1150 to $1750 \mathrm{~m}$. The character of the forest land cover can be seen in Figure 13.3 in SOM. For an example of land cover types, see photos in Figures 13.7.1, 13.7.2 and 13.7.3 in SOM. 
The usual planting of young plants does not damage the soil profiles substantially.

\subsection{Research history}

In 2006, Jiří Crkal found shards of medieval pottery and of a glassmaking pan in the area of one of the forest management earth mounds. During subsequent exploration, the remnants of houses were found. Over the following years, nondestructive research of the glassworks was performed (Crkal, Černá 2009). Metal detector exploration of the built-up area was also performed. It brought an indication of possible iron processing in the village area (Hylmarová et al. 2013). There was also some collection of pottery shards on the mechanically-levelled areas and mounds, performed mainly in the southern and south-western parts of the village area. There was observed an interesting threshold between areas with and without stones (indicating a cleared arable area) on one of these levelled areas. It was at a distance of ca $850 \mathrm{~m}$ in the area we would parcel number as 0 (our numbering system; pers. comm. Jiří Crkal). Research activity from 2010 to 2015 focused on the excavation of one of the households, geodetic measuring of the village terrain remnants, and LIDAR scanning of the area. These excavations and researches have only partly been published up to now. Two smaller researches were performed in the area of the fields: sampling for measuring $\delta^{15} \mathrm{~N}$ values in 2011 (Součková et al. 2013) and excavation of the terrace steps (strip no. 8 , distance $50 \mathrm{~m}$ : two probes of $10 \times 1 \times 0.4 \mathrm{~m}$ ) in 2013. Shards were observed to a depth of $40 \mathrm{~cm}$, but no traces of ploughing were seen in the soil profiles. In 2014, probing and sampling was performed in strips no. 2 to 12 at distances from 50 to $750 \mathrm{~m}$ and, in 2015, probing and sampling from 950 to $1750 \mathrm{~m}$ and background probes were undertaken.

\subsection{Research design}

Soil sampling was based on a regular grid of strips and distances; sampling was only performed in even numberedstrips. In the season 2014, we sampled distances 50, 150, 350,550 and $750 \mathrm{~m}$ and in season 2015, at 950, 1150, 1350, 1550 and $1750 \mathrm{~m}$, as well as five background probes. To assess soil mosaic diversity, we sampled every strip in the 2014 season (from $50 \mathrm{~m}$ to $750 \mathrm{~m}$ ) in three lines named in accordance to their position on the slope within the strip: "higher", "middle" and "lower", three probes thus being sampled in each strip (for the distance combination in this part of the study area, see also sampling pattern in Figure 4). Strip borders were identified by LIDAR scanning and, in some cases, also by terrain observation. At distances from 950 to $1750 \mathrm{~m}$ (season 2015) only the "middle" line was sampled, the reason being the impossibility of safely identifying strip borders due to changes in the surface characteristics because of the forest management. In these parts of the field system, we therefore sampled the probes in a strip-like pattern based on $200 \mathrm{~m}$ steps on an azimuth based on the directions between probes at the 50 and $750 \mathrm{~m}$ distances. Only the probes at the $950 \mathrm{~m}$ distance were placed according to the direction between the probes at the 550 and $750 \mathrm{~m}$ distances. Probes were sometimes placed out of the ideal grid; the usual reasons for repositioning probes were trees, forest management ways, and forest-management soil profiles being damaged by mechanical levelling at distances 950 to $1750 \mathrm{~m}$. Distances of repositioned probes from their ideal location were always less than $10 \mathrm{~m}$. It was possible to place probes in a preserved soil profile in damaged areas where old forest areas or old trees groups had also been preserved. This can be seen in Figure 13.3 in SOM, for example, at distances $1350 \mathrm{~m}$ or $1550 \mathrm{~m}$ (old forest represented by dark green vegetation cover). Only in the case of probe no. 1035 (strip no. 10, distance $1150 \mathrm{~m}$ ) we were unable to find any suitable place (the probe was sampled, but the data was not processed in the analyses). We made 120 probes in the fields and 5 probes for "background" values. We included background probing and analyses to reveal possible relationships of the fields' geochemistry to the presumably uninfluenced environment. Since it was not possible to find an area comparable to the fields that was definitely uninfluenced by past human activities (it was not clear if there were other parcel strips next to parcel strip 13), we still tried to sample in areas distant from the village, at least for comparing soil, geology and vegetation. We therefore tried to avoid sampling in peat bogs, and in areas of unstable soil where trees tend to uproot: both of these environments covered most of the area outside of the fields. Indeed, the background probe sites were the only possible places.

It should be noted that the fields-background relationship was only secondary, as we primarily aimed at intra-field spatial diversity. We saw the amount from 120 field probes as sufficient for obtaining the "intra-field" context and diversity; in addition, we saw the background probes as unnecessary for this primary task. This was also one reason for not placing the probes right in the built-up area (besides which, we did not want to disturb the archaeological features there). However, we saw both these relationships (to the background and to the built-up area) as worthy of study in some separate future research.

The size of probes was ca $40 \times 50 \mathrm{~cm}$ to $50 \mathrm{~cm}$ depth. Their profiles were photographed and described. Since we wanted to compare data across the whole area, we divided horizons into these basic categories (see Table 1 and Figures 13.5.1. to 13.5.8 in SOM): "A" horizon; "E" horizon; and "BD" horizon (which stands for $\mathrm{B}$ darker - i.e. darker facies in upper part of the B horizon). As the B horizon itself was usually several dm thick, we divided it into mechanical layers. The "B30" marked that part of the B horizon between the "BD" horizon and a depth of $30 \mathrm{~cm}$, the following "B3140 " marked depths 31 to $40 \mathrm{~cm}$; for information about the measured depths, see Table 1. Every depth was measured three times; in the case of different or unusual values, two additional measurements were performed. We also took samples of soil material at a $20 \mathrm{~cm}$ depth for potential future analyses. However, the main way of obtaining data was direct field-profile measurement by means of a portable 
ED-XRF (PXRF) analyser Delta Professional, by Olympus InnovX, used in Soil Geochem measurement mode (for applications of XRF spectrometry, see Canti, Huisman 2015; Hürkamp et al. 2009; Kalnicky, Singhvi 2001; Šmejda et al. 2017). It should be stated that this method obtains values of almost the total concentrations of elements in the sediment, as opposed to the usually used methods working mainly with near organic-available fractions. But some studies have used near total concentrations successfully (Entwistle et al. 1998; 2000; Wilson et al. 2005). During taking measurements, we avoided those places whose profile contained parts with only a coarse fraction (above $2 \mathrm{~mm}$ ) present (it was only in a few cases at depths of ca $40 \mathrm{~cm}$ or deeper). All measurements were performed for time for one minute, with $30 \mathrm{~s}$ of the $10 \mathrm{kV}$ beam and $30 \mathrm{~s}$ of the $40 \mathrm{kV}$ beam. The PXRF model used gives data in the form of weight ppm. The quality of the device's measurements was successfully tested by BAS Rudice Ltd. (www.bas.cz) on 55 reference materials (e.g. SRM 2709a, 2710a, 2711a, OREAS 161, 164, 166, RTC 405, 408).

\subsection{Statistical and GIS analyses}

The basic input data for all the analyses was computed as an arithmetic mean for every probe and horizon. The data matrix originating from this process can be seen in SOM, file "Tables", where the data is presented as a whole, and also as data filtered to A, E, BD, B30 and B31-40 horizons. For further analyses we used only these elements: Al, Si, P, K, Ti, $\mathrm{Mn}, \mathrm{Fe}, \mathrm{Zn}, \mathrm{As}, \mathrm{Rb}, \mathrm{Sr}, \mathrm{Zr}, \mathrm{Pb}$, LE (light elements - $\mathrm{H}$ to $\mathrm{Na}$ concentrations lumped together due to the principles of the PXRF method used) which reached at least 505 cases (due to the detection limits not all elements were measured in all cases). The basic matrix therefore consisted of 14 variables and 505 cases. In none of the analyses did we work with the original concentration values. Geochemical data can be generally characterised as (usually) of a non-normal distribution (Limpert et al. 2001; Reimann, Filzmoser 2000) and as compositional data (Reimann et al. 2008; Reimann et al. 2012). According to Reimann et al. 2008, we therefore decided to preferably use clr-transformed data. The abbreviation "clr" stands for centred log-ratio: the data was divided by the geometric mean of their data point and then the values were $\log 10$ transformed. This process helps to avoid some of the problems with compositional data, where the variable cannot reach any value, but is limited by the values of the other variables (Reimann et al. 2008). This process enables the use of additional information in the data matrix (for visualization of this process see Figure 11 in SOM). We used principle component analysis (PCA) as a basic processing method: not only for making the interpretation easier, but also for distinguishing between the possibly different inputs of elements into the soil environment. As the input data for PCA we used the whole matrix. We used Statistica 12 software for PCA. For spatial visualization, we used GIS interpolation (ArcGIS 10.1, Geostatistical wizard tool and the kriging interpolation method). We interpolated the principal components (PCs). An interpolation was performed for the data from the $\mathrm{A}, \mathrm{BD}, \mathrm{B} 30$ and $\mathrm{B} 31-40$ horizons, the majority of the data being in these horizons. For visualization, we used one continuous colour scale for all four horizons. We also wanted to utilize the information about the parcels themselves and also visualize the data for only those areas for which we had data (i.e. the even numbered parcel strips and background area). Therefore, we also used a diffusion kernel for interpolations of those PCs which we interpreted as human related, since it enables the use of barrier features in the interpolation process - in our case, we used the parcel strip borders as such barriers. As we are aware that phosphorus is an almost certain human activity tracer, we have also presented interpolations of its concentration to enable a comparison with the clr-transformation process (Figures 26.1 to 26.4 in SOM). Since we wanted to assess if there were any differences between the strips (manifested by difference in elements / PCA components - and possibly interpreted as human activity tracers) we performed an ANOVA of the human-interpreted PC coordinates from the $\mathrm{BD}$ and B30 horizons together. We performed an ANOVA among the strips for every distance separately, and also an ANOVA among the distances for all strips separately. For a visualization of this, we used the results of a post-hoc Tukey test for differences using R, version 3.1 .2 (2014-10-31) „Pumpkin Helmet“ Copyright (C) 2014 The R Foundation for Statistical Computing (R Core Team 2014).

\section{Results}

\subsection{Macroscopic observations}

Out of 125 probes in total, we have found podzols in 49 cases, cambisols in 65 cases, and 11 cases of juvenile podzolization. As presented in Figure 4 (and in Figure 4.1 in $\mathrm{SOM}$ ), cambisols were more spatially related to the village. There can be two gradients seen in the part between distances 50 and $750 \mathrm{~m}$. The first gradient was along the distance, the second gradient along the altitude. However, the part of the fields between 950 and $1750 \mathrm{~m}$ did not correspond with either of these gradients. There was no clear gradient / pattern interpretable as being related to human activities. We did not observe any other features in the soil profiles, such as traces of ploughing and so on. The Figures 13.5.1 to 13.5.8 are good representatives of soil profile appearances in the area of the fields. We have found pottery shards in some probes: strips 2 and 6 , distance $50 \mathrm{~m}$, and strip 4 at distances 50 and $350 \mathrm{~m}$.

\subsection{PCA results}

PCA extracted 13 components (marked PC 1 to PC 13, see Table 2 for simplified results; and SOM, file "Tables", for complete results). All analysed elements were strongly connected to the first two PCs. Although only the first four PCs reached an eigenvalue greater than 1 , the spatial distribution of PCs enabled those PCs with lesser eigenvalues to also be interpreted: especially PC 4 and PC 7. For visualizations of the interpolation, please see Figures 5 to 8 (chosen PCs and 
Table 2. Variables loadings of nine principal components. PCA results: loadings of variables. Only values $\leq-0.25$ and $\geq 0.25$ are depicted, values $\leq-0.7$ and $\geq 0.7$ marked in bold. All data including components 10 to 13 can be seen in SOM, PCA eigenvalues and PCA loadings.

\begin{tabular}{|c|c|c|c|c|c|c|c|c|c|}
\hline & PC 1 & PC 2 & PC 3 & PC 4 & PC 5 & PC 6 & PC 7 & PC 8 & PC 9 \\
\hline $\mathrm{Al}$ & 0.65 & & -0.46 & -0.28 & 0.49 & & & & \\
\hline $\mathrm{Si}$ & 0.63 & -0.67 & & & & & & & \\
\hline $\mathrm{P}$ & -0.73 & & & -0.46 & & & 0.4 & & \\
\hline K & 0.88 & -0.31 & & & & & & & \\
\hline $\mathrm{Ti}$ & 0.91 & & & & & & & & \\
\hline $\mathrm{Mn}$ & 0.32 & 0.84 & & & & -0.26 & & 0.31 & \\
\hline $\mathrm{Fe}$ & & 0.79 & 0.34 & & & 0.41 & & & \\
\hline $\mathrm{Zn}$ & & 0.74 & -0.41 & 0.28 & & & & & \\
\hline As & -0.70 & -0.57 & 0.40 & & & & & & \\
\hline $\mathrm{Rb}$ & 0.86 & & & -0.31 & & & & & \\
\hline $\mathrm{Sr}$ & 0.76 & & & 0.44 & -0.25 & & & & 0.26 \\
\hline $\mathrm{Zr}$ & 0.85 & & & & & & & & -0.31 \\
\hline $\mathrm{Pb}$ & -0.82 & -0.5 & & & & & & & \\
\hline LE & -0.60 & & -0.60 & & -0.30 & 0.28 & & & \\
\hline Eigenvalue & 6.53 & 3.09 & 1.15 & 0.95 & 0.66 & 0.47 & 0.37 & 0.24 & 0.23 \\
\hline Cumulative \% & 46.70 & 68.74 & 76.98 & 83.73 & 88.44 & 91.82 & 94.48 & 96.22 & 97.86 \\
\hline
\end{tabular}

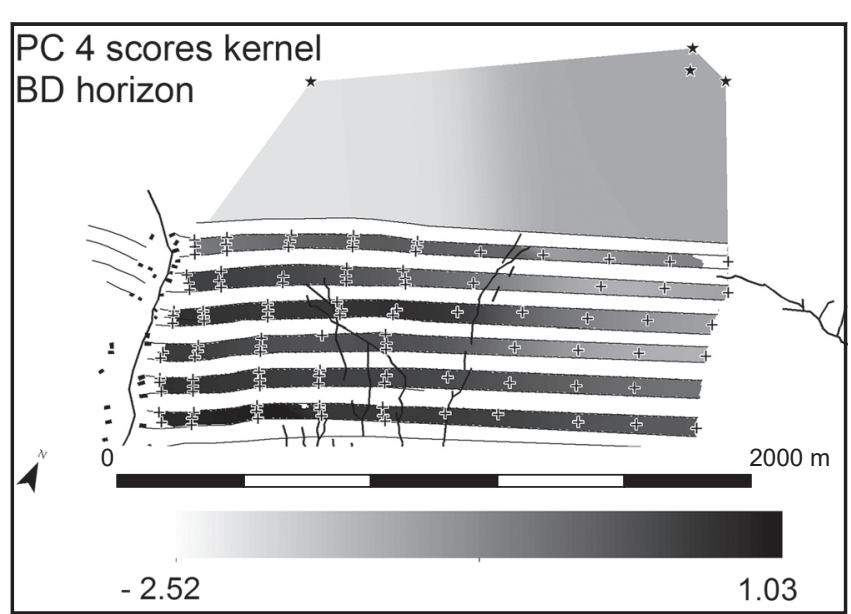

Figure 5. Kernel interpolation of PC 4 in the BD soil horizon. See colour versions in Figures 20.2 and 21.2 in SOM.

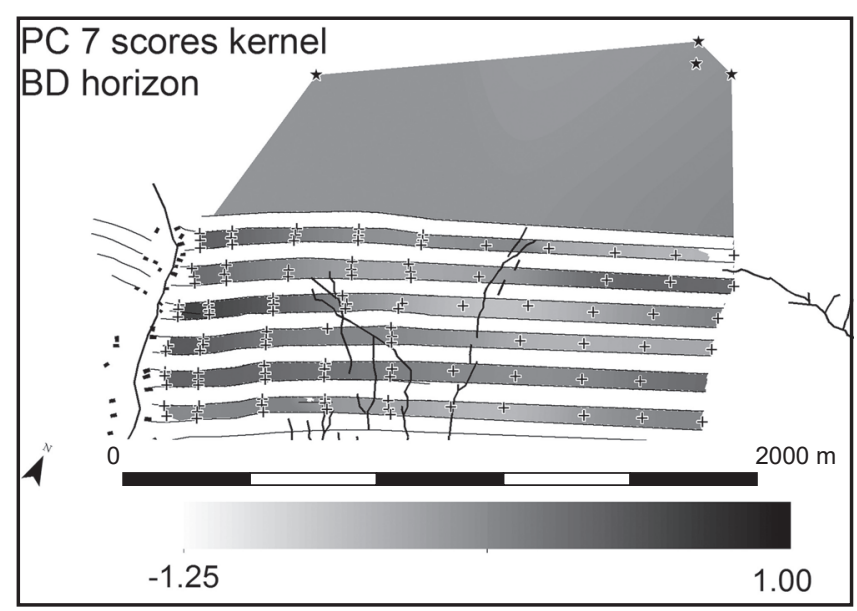

Figure 7. Kernel interpolation of PC 7 in the BD soil horizon. See colour versions in Figures 24.2 and 25.2 in SOM.

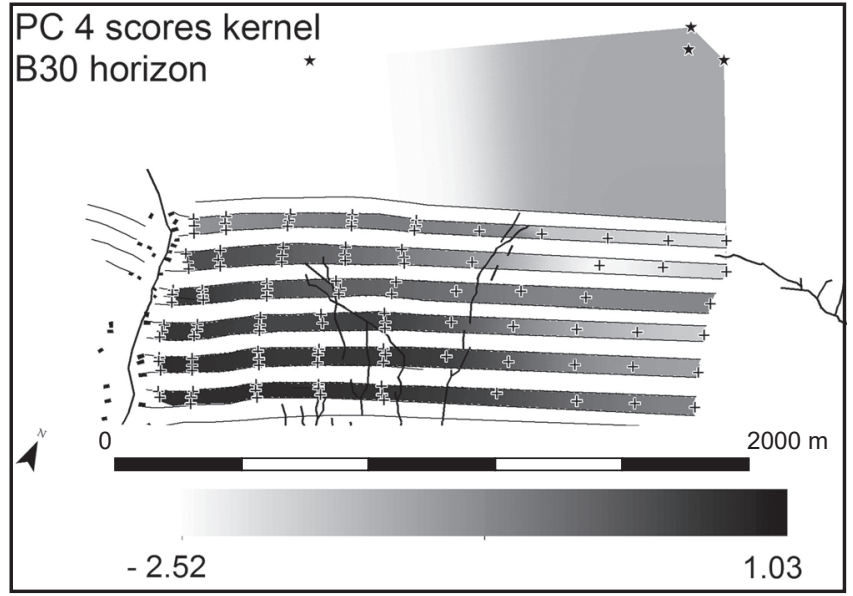

Figure 6. Kernel interpolation of PC 4 in the B30 soil horizon. See colour versions in Figures 20.3 and 21.3 in SOM.

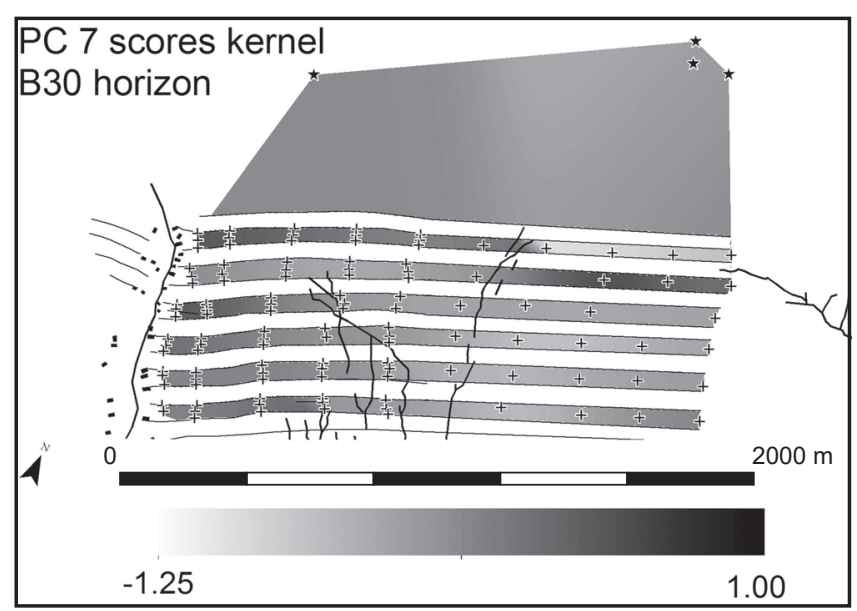

Figure 8. Kernel interpolation of PC 7 in the B30 soil horizon. See colour versions in Figures 24.3 and 25.3 in SOM. 
horizons) and also Figures 17.1 to 25.4 in SOM (coloured versions for PC 1 to PC 7 in all soil horizons). For PCs' relation to altitude, depth and distance, see Figures 16.1 to 16.3 in SOM, and for relation to podzols see Figure 15.2 in SOM.

PC 1 was positively connected to geogenic elements, such as $\mathrm{Ti}, \mathrm{Rb}, \mathrm{Sr}, \mathrm{Zr}, \mathrm{Al}$ and $\mathrm{Si}$, and negatively to $\mathrm{P}, \mathrm{As}$, $\mathrm{Pb}$ and $\mathrm{LE}$. Its values were manifested mainly in the vertical dimension: the manifestation of negative values being in the A horizon and positive values oppositely in the
B31-40 horizon. There was no clear connection to altitude; yet there was a visible relation to depth and a very subtle relation to distance from the village (negative values were manifested more in proximity to the village). There was also no difference in the values between sites with and without podzol E horizon. PC 2 was connected mainly to $\mathrm{Mn}, \mathrm{Fe}$ and $\mathrm{Zn}$, and negatively to $\mathrm{Si}, \mathrm{As}$ and $\mathrm{Pb}$. A clear vertical gradient was also found: positively connected elements were manifested mainly in the B31-40 horizon, and furthermore

Differences among strips

ANOVA performed on every distance separately segments connect sites (combination of strip and distance) with statistically significant $(\mathrm{p}<0.05)$ difference according to post-hoc Tukey test input data: PC 4 scores from BD and B30 horizons

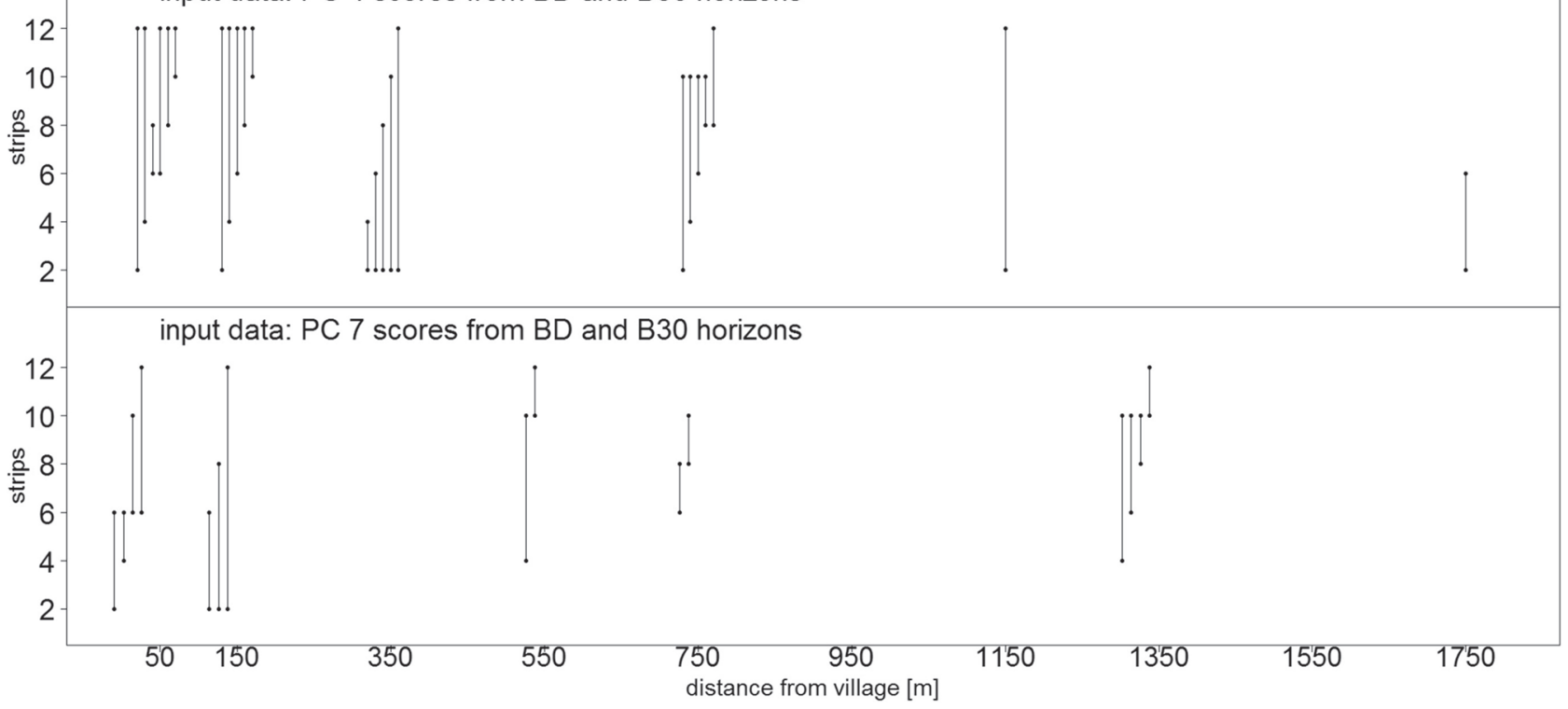

Figure 9. Visualization of the Post-hoc Tukey test: differences among strips. Segments indicate pairs of sites with statistically-significant differences.

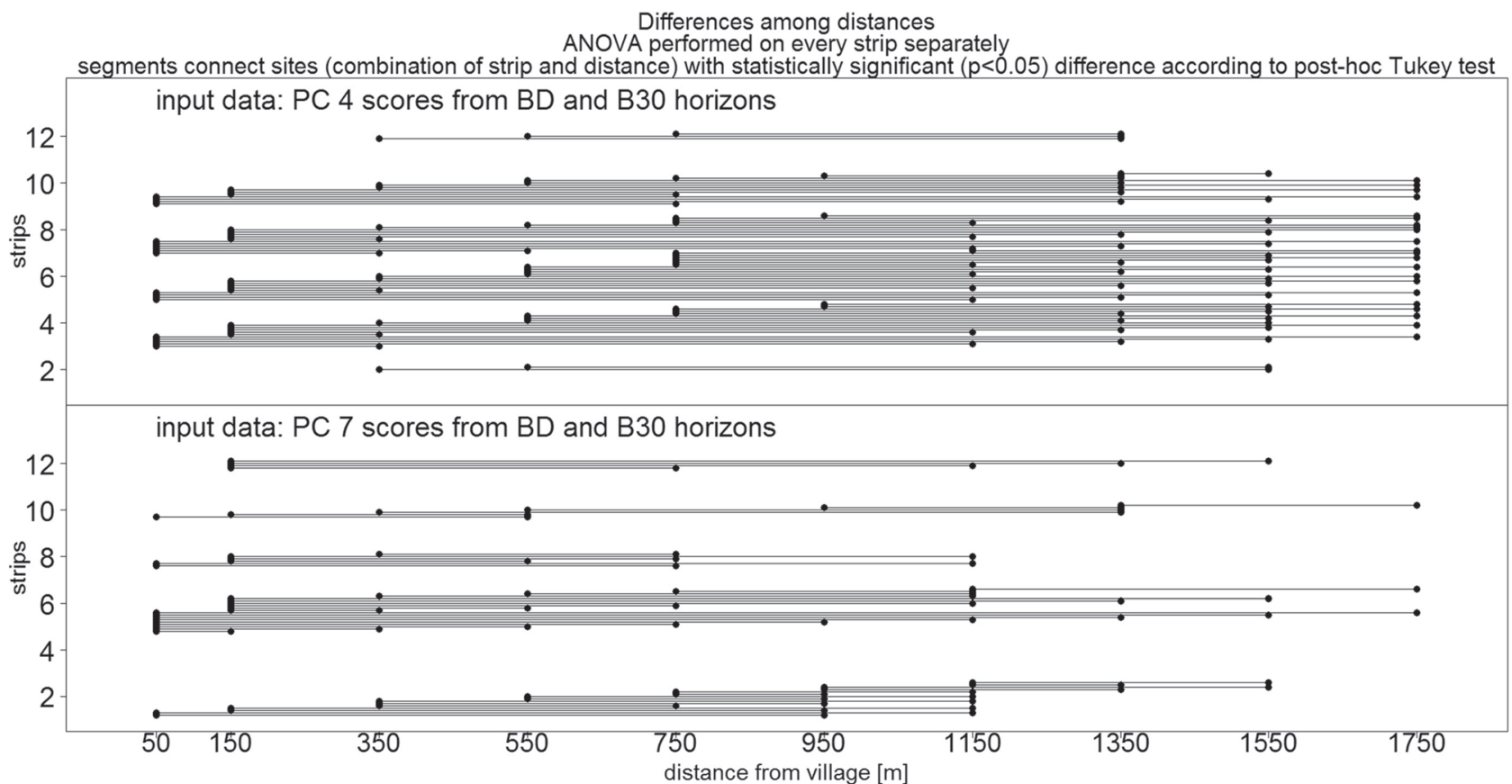

Figure 10. Visualization of the Post-hoc Tukey test: differences among distances. Segments indicate pairs of sites with statistically-significant differences. Only pairs of sites of mutual distance under $400 \mathrm{~m}$ presented. For all differences see Figure 10.1 in SOM. 
in the vicinity of the village. A slight relation to altitude, depth and distance was also observed. PC 3 was connected to Al, $\mathrm{Zn}$ and LE (negatively), and to Fe and As (positively). For PC3, no clear patterns were found in the spatial distribution. $\mathrm{PC} 4$ was related to $\mathrm{Zn}$ and $\mathrm{Sr}$ (positively), and to $\mathrm{Al}, \mathrm{P}$ and $\mathrm{Rb}$ (negatively). A clear spatial relation of positive values to the village was observed in all soil horizons; there was also a clear decreasing pattern along the distance gradient. PC 5 was related mainly to $\mathrm{Al}$ and $\mathrm{Sr}$; no clear pattern was found. We have also found no clear pattern in the case of PC 6 related to Fe, LE and Mn. PC 7 was positively related to P. This PC was spatially manifested mainly in the village vicinity in all soil horizons; there was also a decreasing pattern along the distance gradient. PCs 8 and 9 were of no clear pattern.

\subsection{ANOVA}

Since we presume PCs 4 and 7 to be the tracers of human activity, we performed an ANOVA on them. The results of the post-hoc Tukey test can be seen in Figures 9 and 10 . Clearly, there were more differences among the distances than among the strips. PC 4 recorded more diversity than PC 7. The diversity among strips was based mainly on the presence of one separate strip that was different from all other strips.

\section{Discussion}

\subsection{PCA}

We interpreted PCs 1, 2, 4 and 7. Other PCs were not so clearly interpretable. PC 1 was a representation of a contrast between the natural, geogenic part of the local geochemistry, and the anthropogenic inputs. The natural part represented by geogenic elements was manifested mainly in deeper horizons. Anthropogenic inputs were manifested mainly in the topsoil A horizon, suggesting an origin for the $\mathrm{As}$ and $\mathrm{Pb}$ in the atmospheric deposition, probably originally coming from man-made pollution. LE (and probably P too) in PC 1 represent the organic matter in the topsoil. PC 2 has been interpreted as a representation of two probably-anthropogenic inputs: $\mathrm{As}$ and $\mathrm{Pb}$ again representing pollution from the atmospheric deposition input; positively correlated $\mathrm{Mn}, \mathrm{Zn}$ and $\mathrm{Fe}$ probably representing historic anthropogenic input from the medieval village. This interpretation was based on the spatial relation of the positive values to the village vicinity; these elements also tend to record anthropogenic activities. Despite this interpretation, we have not used this $\mathrm{PC}$ in other analyses due to the fact that the historic activity was recorded mainly in the deepest horizon (B31-40). There is also the question of the division of $\mathrm{As}$ and $\mathrm{Pb}$ into the first two PCs and the possible historic or ancient origin of at least part of this pollution. Could the $\mathrm{As}$ and $\mathrm{Pb}$ be related to some non-agrarian activity, e.g. iron processing in the village, or generally to medieval or older mining or smelting activities in the Ore Mountains? Such a possibility has been recently presented (Veron et al. 2014) for a peat bog profile from the Ore Mountains by isotopic analyses.
PC 4 was interpreted as a representation of village activities recorded in the input of the usually human-related elements $\mathrm{Zn}$ and Sr. These were also spatially manifested mainly in the village vicinity. The presence of $\mathrm{P}$ and its negative correlation with PC 4 remained uninterpreted. Phosphorus should be a candidate for a human activity tracer too, but we did not found a clear interpretation of it for this PC; its spatial distribution (see blue colours in Figures 20.1 to 20.4 and 21.1 to 21.4 in SOM) was clearly based on high values of $\mathrm{P}$ concentrations (see Figures 26.1 to 26.4 in SOM). The absolute values of $\mathrm{P}$ concentrations in the local geochemistry clearly recorded different inputs than that of the medieval village. The transformation and statistical procedures (PCA) helped to improve the data structure: analysing only the concentrations would not have been sufficient here. We have also been able to obtain a separate record of human activities recorded by $\mathrm{P}$. It was from $\mathrm{PC} 7$, related only to $\mathrm{P}$ and also spatially related to the village vicinity. Besides that, distant parts of the field system were also manifested, though not so heavily (see Figures 24.1 to 24.4 and 25.1 to 25.4 in SOM).

\subsection{Relations to other features}

We also tried to examine the relation of PCA results to the features in the area, especially to charcoal burning sites, glassworks, stone heaps, water streams and, of course, to the podzol distribution. The relation to podzols was one of the main aims of this study, since we presumed that its spatial distribution has been influenced by human activities in the past (as was shown, for example, by Kristiansen 2001). Surprisingly, the relationships of PCs to podzols were very faint. We examined the ratios of PCs' case coordinates between horizons (podzolization is generally characterized by a downward transport of fine soil material, including ions, organic matter, clay minerals and so on, based mainly on acid $\mathrm{pH}$ and higher precipitation; therefore the ratio between vertical levels should indicate such transport). The results were visualized in the form of box plots (see Figure 15.2 in SOM). We also added the results of the same analytic data processing of element concentrations for comparison. The results were different: almost all elements recorded differences between "yes" and "no" podzols (Figure 15.1 in SOM). However, the PCs recorded the differences in only a few cases: PC 4 recorded a difference between A and B30 horizons; PC 7 recorded no difference.

There were many places of charcoal burning. The spatial distribution of the PCs mainly reflected these sites in those cases where the PC was related to $\mathrm{Zn}$ (PC 2 and 4). This was clearly reflected in site 823 (strip no. 8, distance $750 \mathrm{~m}$ ), where the probe was placed directly in a charcoal-burning hearth (values of $\mathrm{Zn}$ here were higher than usual). Indications of a relationship between these PCs and charcoal-burning sites were found, for example, in the case of PC 4 (BD horizon - see Figure 5, and also Figure 20.2 in SOM). The spatial distribution of PC 4 could be influenced by the distribution of charcoal-burning sites both were placed mainly in the village vicinity.

Three probes were placed right in the area of glassworks (studied by Crkal and Černá 2009) in strip no. 4, at a distance 
of $750 \mathrm{~m}$. This site showed no distinctive values for any of the PCs. Only PC 5 in the BD horizon (Figure 22.2 in SOM) reflected this area, but no clear relationship was observed in other horizons. The spatial distribution of stone heaps was bound to only a small part of the whole fields system: in the western corner of the study area with no clear relation to any of the geochemical characteristics. Water stream areas were researched mainly in the central part of the fields system, between distances of ca 550 to $950 \mathrm{~m}$. It could be seen on maps that this area had no substantial influence on the geochemical situation. Only in the case of PC 3 could some weak relation be seen (BD horizon - Figure 19.2 in SOM).

Interpretation of the background probes was also interesting. The idea of a geochemical background is complicated: there are many definitions of it (see Reimann and Garrett 2005). Archaeology, especially, should be aware of the fact that - with its necessity of using of a long-term view - the natural background has changed substantially during prehistory and history. It is more a rhetorical question than a real one: is there a natural geochemical background to be found in such regions as those we deal with in Europe? Our research in Spindelbach has found that the problem of "background" can be really difficult to design and interpret. The concentrations of phosphorus were highest in two of the "background" probes. At this stage in our research, we cannot interpret it clearly: it could be due to unknown human activity placed there, or due to a different $\mathrm{P}$ input into the soil unrelated to human activity. A decision would require further research. Generally, the difficulty of finding an uninfluenced background is the norm in regions of dense settlement. The Spindelbach example has clearly shown that it could also be a problem to find a background in extreme and marginal areas, or, the design of "background" probes placement would have to be based on different ideas to that of only "the background can be found anywhere outside the human-influenced area". An important result from the Spindelbach background research was that it would be problematic to only work with just concentrations: the possible "background" recorded the highest levels of phosphorus concentrations. This should be resolved by the research design or by using appropriate analyses. In our case, this was resolved by using multivariate statistics able to distinguish different element inputs.

Similarly, we could discuss a possible relation to the other extreme of human activity - the built-up area. This would probably not just mean extreme values of human influence recorded in the fields, but would be combined with other human activities not reflected in the geochemistry of the fields. The relation of the fields' geochemistry to both the background and to the built-up area should be analysed in separate future research (not focused primarily on the fields as we have done) with a suitable design of sampling (e.g. same numbers of probes in all categories, same or similar pattern of placing of probes) and with a suitable interpretational approach (e.g. dealing with a radically different spatial diversity in all categories). It should be noted that the geochemical record of human activities in the built-up area was analysed in another research performed at Spindelbach (record in alluvial sediments).

\subsection{Ploughing}

We have not found any traces of ploughing in the soil profiles. Possible reasons for this are: 1) the research design as we performed it did not primarily focus on searching for these traces; 2) in addition, the dimensions of the probes were small (although we did not find any traces in larger probes focused on the terrace steps performed in the 2013 season); 3 ) pedogenesis (mainly podzolization processes) have erased possible traces and therefore the soil profile has changed through the period since the village abandonment. Of course, one could express an objection to this interpretation: maybe there was no ploughing performed at all. But this possibility should be treated as nearly impossible due to the following reasons: 1) historical impossibility: even in villages producing non-agricultural goods for trade, agricultural activities (that included arable fields) were performed for the subsistence of the villagers themselves; 2) the terrace system preserved in Spindelbach was a clear evidence of ploughing, for terraces were created by ploughing in order to make ploughing in slope areas easier and to prevent soil erosion; 3) pottery shards found at depths to $40 \mathrm{~cm}$ (in season 2013 probes); 4) pottery shards found in probes of 2014 season; 5) field clearing of stones found on one of the mechanically-levelled areas at distance $800 \mathrm{~m}$ (pers. comm. Jiří Crkal). It should be one of the tasks for future research at Spindelbach to focus on soil traces and the micromorphology in more detail.

\subsection{Differences in land use and management}

This was one of the main aims of this study: to find out if there were spatial differences in human activity tracers. Some differences and gradients could be seen. The spatial distribution of the PCs 4 and 7 (Figures 5 to 8, and 20.1 to 21.4 and 24.1 to 25.4 in SOM) has brought some information. A major difference was observed between the village vicinity and the distant parts of the field system. The village vicinity was related to the clear manifestation of both PC 4 and PC 7 (and also to PC 2 in B31-40 horizon) and we could interpret this as more intensively-managed arable fields. The distant part was only related to the weaker manifestation of PC 7. We could interpret such patterns in this way: 1) intensivelymanaged arable fields in the village vicinity; 2) arable fields with weaker management in distant parts; 3) probably pastures in the central part with the water streams. The management of distant parts was also indicated by the finding of a whetstone (see Figure 12 in SOM) in strip 6, ca 1250 m from the village. The management itself was diversified by two tracers of different inputs: 1) PC 4 with $\mathrm{Zn}$ and Sr; 2) PC 7 with P. Thus PC 7 could easily be connected to the manuring of arable fields. PC 4 could be seen as a tracer of ash ( $\mathrm{Zn}$ ) or of household midden (Sr) input (references hereafter). The spatial distribution restricted to the area of the strips revealed some differences: PC 4 and the difference of strip 12 in BD and B30 horizons; PC 7 and the differences among strips in the $50 \mathrm{~m}$ distance; or the differences among 
strips 8,10 and 12 in BD and B30 horizons. ANOVA and Post-hoc Tukey tests showed that only a part of these visually found differences (on interpolation maps) was also statistically significant. The visualization of significantlydifferent couples of sites by Post-hoc Tukey test can be seen in Figures 9 and 10. This is a clear indication that the general use of only maps or values (e.g. concentrations) is insufficient; the visual observation of the data on its own could provide false interpretation. In our case, ANOVA showed that only part of the visually-observed diversity was based on the data (not on map visualisation settings). It was clear that the human activity tracers were more diversified with distance from the village than among the strips. PC 4 was more diversified in both strips and distances than PC 7. There were observed two basic patterns of diversity: 1) differences between mutually distant sites generally; 2) one site being different from all other sites. The mutual distance of two different sites influenced the interpretation: the nearer the sites, the more the difference could be interpreted as a result of intentional management. The more distant, the more it could be interpreted as a result of general management, land use categories and so on. The first pattern of distance differences was mainly observed along distances in the strips (Figure 10 presents only sites of mutual distance under $400 \mathrm{~m}$; for all distances, please see Figure 10.1 in SOM). We could interpret this as a combination of land use categories (arable fields, pastures, forests) and of the intensity of management in these areas. It indicates that there were few distinct changes or rapid gradients of management in the strips. There was a threshold at the distance of $350 \mathrm{~m}$, recorded mainly by PC 4 in strip 4, 6 and 8. Both PC 4 and PC 7 recorded that there was more diversity in the vicinity of the village than in the distant parts of the field system. The second pattern was observed more among the strips (Figure 9). This would indicate that for every distance there was generally similar management intensity in all strips, but in a few cases, management rapidly became different from the one generally observed. We could probably see this as a difference in management intensity. The diversity of both patterns can be at least partially interpreted as the result of a diversity of intentionally-placed management and its intensity.

It should also be noted that there was no clear decreasing pattern of the human-connected PCs along a distance gradient. As can be seen in Figure 16.3 in SOM, PC 4 recorded roughly similar values in the village vicinity, which then decreased in the distant parts of the field system. PC 7 decreased in the village vicinity and then rose again in the distant parts of the field system. The smaller diversity among strips has shown that there were differences in management among households, but the general pattern of field system structure was similarly followed by householders.

One could interpret the householders as utilizing the possibilities of the independent management of their own possessions, but generally they followed the usual pattern of Waldhufendorf field systems. The diversity based on land-use categories still seems to be more profound than the diversity based only on householder management strategies.

Furthermore, it should be stated that other processes could also influence the interpreted results. These are mainly: 1) different times for the performance of human activities; 2) different times for the abandonment of fields; 3) natural processes such as leaching (although no clear and no positive relation between human tracers and podzolization was observed!); 4) other soil processes. Some of the above could be clarified by archaeological research of the households, and some by more specialized pedochemical research.

\subsection{Comparison with other studies}

We have found that the decreasing manifestation of the human-connected PCs with distance from the village cannot be considered as correct. Such a general presumption of a simple decreasing trend could not be accepted considering the entire length of the parcel strips. Although we did not sample the complete lengths (we do not know the actual length, but it was probably longer than the sampled $1750 \mathrm{~m}$ ), the sampled parts showed non-linear trends in the humanactivity tracers. The general presumption of a decrease is usually based on the research design: 1) sampling is not continuous, but rather categorical as "infield" and "outfield" (e.g. Davidson et al. 2007, where the $\mathrm{P}$ values were higher in the infield than in the outfield); 2) the sampling is linear, but the fields are not sampled to a sufficient length (e.g. by Součková et al. 2013 who found a decreasing trend of $\delta^{15} \mathrm{~N}$ in the Spindelbach fields). The indications of a decreasing trend were also based on historic evidence. Krenzlin (1952: Figure 5) has shown that manured areas were spatially adjacent to the built-up area of the village (with the note that the village of that example was not Waldhufendorf). The visualization of the manured area also showed that these areas were not of the same extent among the parcel strips. Unfortunately, we could not see the spatial distribution of the manuring intensity. The diversified intensity of manuring has also been shown by Jones (2009). His study used a number of shards as the bearer of information, and also showed that the manuring not only had a connection to economic strategies but also to purely cultural concepts.

Using the multi-element analyses, we found the following elements somehow connected to the village: $\mathrm{Zn}, \mathrm{Sr}$ and possibly Mn (PC 2 and 4), and P standing alone in PC 7. There are many studies focusing on multi-element analyses bringing similar results (Bindler et al. 2011; Bing et al. 2011; Costa 2011; Davidson et al. 2007; Entwistle et al. 1998, 2000; Facchinelli et al. 2001; Horák, Hejcman 2016a; 2016b; Sollito et al. 2010; Walkington 2010; Wilson et al. 2009). It was also shown that it is highly suitable to work more with the multivariate analyses results rather than with the original concentrations, or the transformed concentrations, i.e. rather than with generally only separate input variables, such as elements. This was mainly shown, in the examples of PCs 1, 4 and 7, which separated the different inputs of phosphorus, the main anthropogenic tracer above all (the difference between the possibilities can be particularly seen in the comparison of PC interpolations vs concentration interpolations - see 
Figures 26.1 to 26.4 in SOM). This approach is more used in the geochemical literature (e.g. Facchinelli et al. 2001) than in the archaeological literature, where the analysis of separate elements prevails (e.g. Bindler et al. 2011; Wilson et al. 2005), although in some cases multivariate analyses are being used to find the connections (Entwistle et al. 1998; 2000; Wilson et al. 2008, 2009). There should also be more research of soils in the areas of abandoned villages, not only in general gradients or in regular grids, but also with respect to different possessions. This has a potential not only for human-soil relationships, but also to purely historic questions.

There are also studies working with podzosols and archaeological features (Kristiansen 2001). Our study has shown that podzolization processes can be very rapid: the macroscopically distinguishable E horizon was well developed in the ploughed areas ca 600 years ago. Compared to the study of Kristiansen (2001), we have found only one indication of the possible relation between human activities and podzol spatial distribution ( $\mathrm{PC} \mathrm{4,} \mathrm{only} \mathrm{the} \mathrm{ratio} \mathrm{of}$ horizons A to B30). PC 7 connected to phosphorus did not reveal any relation to podzolization.

\section{Conclusion}

Our study has shown that multi-elemental analyses can bring information not only about the identification of places of historical human activities, but also information about the internal structure of fields, which can be interpreted in terms of management, its intensity, and the preferential placing of fields. There was diversity between the parcel strips and also, most importantly, diversity within the parcel strips. Although some of this between- and within- strips diversity could be explained by land-use type diversity, some was explainable by household differences and by the preferences of peasants. The podzolization (or pedogenetic processes generally) had covered any macroscopic traces of ploughing. The spatial distribution of podzols revealed it to be independent of the human activities or to have a dependency only on particular activities - types of manuring or soil improvement management. The research also revealed that it is possible to obtain interpretable results by portable XRF terrain measuring. Future research could focus on using more methods (isotopic, general sedimentology - such as grain sizes, organic content, pottery shard presence and quantification, etc.) in interesting gradients, and also directly on interesting places such as the glassworks or charcoalburning sites.

\section{Acknowledgement}

This research was supported by the Czech Science Foundation, project No P405/12/P715 (T. Klír) and by the Charles University Grant Agency, project No. 307415 (J. Horák). We also want to thank the Faculty of Arts of
Charles University, our students for their help with the realization of this project, and Jiří Crkal for his useful help and experience with Spindelbach. We also wish to thank the reviewers for their helpful and inspiring comments.

\section{References}

AČ V - Archiv český, čili staré písemné památky české i moravské. Palacký, F. (ed.) Pragae 1862. [The Czech archive or old written historical sources from Bohemia and Moravia]. Available also online: http://147.231.53.91/ src/index.php? $=\mathrm{s} \&$ cat $=10 \&$ bookid $=194 \&$ page $=1$ (cited $8^{\text {th }}$ December 2015).

ANDERSSON, H., SCHOLKMANN, B., KRISTIANSEN, M. S. 2007: Medieval Archaeology at the Outset of the Third Millenium: Research and Teaching. In: Graham-Campbell, J., Valor, M. (Eds.): The Archaeology of Medieval Europe. Volume 1. Aarhus, 19-45.

BINDLER, R., SEGERSTRÖM, U., PETTERSON-JENSEN, I.-M., BERG, A., HANSSON, S., HOLMSTRÖM, H., OLSSON, K., RENBERG, I. 2011: Early medieval origins of iron mining and settlement in central Sweden: multiproxy analysis of sediment and peat records from the Norberg mining district. Journal of Archaeological Science 38, 291-300.

BING, H., WU, Y., SUN, Z., YAO, S. 2011: Historical trends of heavy metal contamination and their sources in lacustrine sediment from Xijiu Lake, Taihu Lake Catchment, China. Journal of Environmental Science 23, 1671-1678.

BORK, H.-R., BORK, H., DALCHOW, C., FAUST, B., PIORR, H.-P., SCHATZ, T. 1998: Landschaftsentwicklung in Mitteleuropa. KlettPerthes, Gotha, Stuttgart.

BORN, M. 1977: Geographie der ländlichen Siedlungen 1. Die Genese und Siedlungsformen in Mitteleuropa. Studienbücher der Geographie. Stuttgart.

CANTI, M., HUISMAN, D. J. 2015: Scientific advances in geoarchaeology during the last twenty years. Journal of Archaeological Science 56, 96-108.

CERMAN, M. 2002: Soziale Differenzierung, proto-industrielle Entwicklung und Gutherrschaft in Frýdlant und Liberec, 16.-18. Jahrhundert. In: Cerman, M., Zeitlhofer, H. (Eds.): Soziale Strukturen in Böhmen. Ein Regionaler Vergleich von Wirtschaft und Gesselschaft in Guttherrschaften, 16.-19. Jahrhundert. Sozial- und Wirtschaftshistorische Studien 28. Wien - München. 174-191.

CERMAN, M., MAUR, E. 2000: Proměny vesnických sociálních struktur v Čechách 1650-1750. Der Wandel der ländlichen Sozialstrukturen in Böhmen, 1650-1750. Český časopis historický 98, 737-774.

CHRISTIE, N., STAMPER, P. (Eds.) 2012: Medieval Rural Settlement. Britain and Ireland, $A D$ 800-1600. Oxford.

COSTA, D. M. 2011: Archaeo-environmental study of the Almas river: mining pollution and the Cerrado biome in the end of the nineteenth century in Mid-Western, Brazil. Journal of Archaeological Science 38, 3497-3504.

CRKAL, J., ČERNÁ, E. 2009: Nové objevy v Krušných horách - zaniklé středověké sklárny na k.ú. Výsluní, okr. Chomutov. New Discoveries in the Krušné Hory Mountains - A Defunct Medieval Glassworks near Výsluní, Chomutov. Archaeologia historica 34, 503-522.

DAVIDSON, D. A., WILSON, C. A., MEHARG, A. A., DEACON, C., EDWARDS, K. J. 2007: The legacy of past manuring practices on soil contamination in remote rural areas. Environment International 33, 78 83.

DE MOOR, M., SHAW-TAYLOR, L., WARDE, P. 2002: The Management of Common Land in North-west Europe, c. 1500-1850. Comparative Rural History of the North Sea Area 8. Turnhout.

ENTWISTLE, J. A., ABRAHAMS, P. W., DODGSHON, R. A. 1998: MultiElement Analysis of Soils from Scottish Historical Sites. Interpreting Land-Use History Through the Physical and Geochemical Analysis of Soil. Journal of Archaeological Science 25, 53-68.

ENTWISTLE, J. A., ABRAHAMS, P. W., DODGSHON, R. A. 2000: The Geoarchaeological Significance and Spatial Variability of a Range of Physical and Chemical Soil Properties from a Former Habitation Site, Isle of Skye. Journal of Archaeological Science 27, 287-303. 
FACCHINELLI, A., SACCHI, E., MALLEN, L. 2001: Multivariate statistical and GIS-based approach to identify heavy metal sources in soils. Environmental Pollution 114, 313-324.

FRANDSEN, K.-E. 1983: Vang og taegt. København.

HALL, D. 2014: The Open Fields of England. Mediaeval History and Archaeology. Oxford.

HOFFMANN, R. C. 2014: An Environmental History of Mediaeval Europe Cambridge Mediaeval Textbooks. Cambridge.

HOLLIDAY, V. T. GARTNER, W. G. 2007: Methods of soil P analysis in archaeology. Journal of Archaeological Science 34, 301-333.

HOPCROFT, R. L. 1999: Regions, Institutions, and Agrarian Change in European History. Ann Arbor.

HORÁK, J., HEJCMAN, M. 2016a: 800 years of mining and smelting in Kutná Hora region (the Czech Republic) - spatial and multivariate meta analysis of contamination studies. Journal of Soils and Sediments 16, 1584-1598.

HORÁK, J., HEJCMAN, M. 2016b: Contamination characteristics of the confluence of polluted and unpolluted rivers - range and spatial distribution of contaminants of a significant mining centre (Kutná Hora, Czech Republic). Soil and Water Research 11, 235-243.

HÜRKAMP, K., RAAB, T., VÖLKL, J. 2009: Two and three-dimensional quantification of lead contamination in alluvial soils of a historic mining area using field portable X-ray fluorescence (FPXRF) analysis. Geomorphology 110, 28-36.

HYLMAROVÁ, L., KLÍR, T., ČERNÁ, E. 2013: Kovové předměty ze zaniklého Spindelbachu v Krušných horách. K výpovědi detektorového průzkumu - Iron Objects from the Defunct Village of Spindelbach, Krušné hory Mountains. Results of metal detecting. Archaeologia historica 38, 569-609.

JONES, R. 2009: Manure and the Medieval Social Order. In: Allen, J. A., Sharpless, N., O'Connor, T. (Eds.): Land and People. Papers in memory of John G. Evans. Prehistoric Society Research Paper 2. 215-225.

KALNICKY, D.J., SINGHVI, R. 2001: Field portable XRF analysis of environmental samples. Journal of Hazardous Materials 83, 93-122.

KLÍR, T. 2008: The Settlements and Agriculture of the Margins in the Later Middle Age and Early New Age. Dissertationes Archaeologicae Brunenses / Pragensesque 5. Praha.

KLÍR, T. 2010a: Osídlení horských oblastí Čech ve středověku a raném novověku - východiska interdisciplinárního výzkumu. Settlement in Mountainous Areas of Bohemia in the Middle Ages and the Early Modern Age Period - Points of Departure for Interdisciplinary Research. Archaeologia Historica 35, 373-391.

KLÍR, T. 2010b: Rural settlements in Bohemia in the "age of transition" $\left(14^{\text {th }}-16^{\text {th }}\right.$ century): research concept and preliminary report. Medieval Settlement Research 25, 52-61.

KLÍR, T. 2013: Agrarsysteme des vorindustriellen Dorfes. Zur Interpretation mittelalterlicher Ortswüstungen im Niederungs- und Mittelgebirgsmilieu. In: Theune, C. (Ed.): Stadt - Land - Burg. Festschrift für Sabine Felgenhauer-Schmiedt zum 70. Geburtstag. Internationale Archäologie, Studia honoraria 34, Leidorf, 139-157.

KLÍR, T. 2016: Zaniklé středověké vsi ve výzkumném záměru Ústavu pro archeologii Univerzity Karlovy v Praze. Zaniklý Spindelbach (Krušné hory), Kří a Hol (střední Čechy). In: Nocuń, P., Fokt, K., Przybyła-Dumin, A. (Eds.): Wieś zaginiona. Stan i perspektywy badań. Seria: Monografie i materiały MGPE 5, Chorzów, 17-58.

KLÍR, T., KENZLER, H. 2009: Srovnávací studium areálů zaniklých středověkých vesnic na základě analýz fosforečnanů. Zaniklá stř̌edověká vesnice Schwarzenbach u Chebu - A Comparative Study of Deserted Mediaeval Villages on the Basis on Phosphate Analyses: Schwarzenbach, near Cheb. Archaeologia Historica 34, 657-680.

KÖTSCHKE, R. 1953: Ländliche Siedlung und Agrarwesen in Sachsen. Forschungen zur Deutschen Landeskunde 77. Remagen / Rhein.

KRAJÍC, R. 1983: Přehled archeologických výzkumů ve středověku na Táborsku (se zaměřením na zaniklé středověké osady). Übersicht über die archäologischen Erforschungen des Mittelalters im Gebiet von Tábor mit besonderer Berücksichtigung der mittelalterlichen Dorfwüstungen. Archeologické výzkumy v jižních Čechách 1, 95-127.

KRENZLIN, A. 1952: Dorf, Feld und Wirtschaft im Gebiet der Grossen Täler und Platten östlich der Elbe. Forschungen zur deutschen Landeskunde 70. Remagen.

KRISTIANSEN, S. M. 2001: Present-day soil distribution explained by prehistoric land-use: Podzol - Arenosol variation in an ancient woodland in Denmark. Geoderma 103, 273-289.

KRÜGER, R. 1967: Typologie des Waldhufendorfes nach Einzelformen und deren Verbreitungsmustern. Göttinger Geographische Abhandlungen 42. Göttingen.

KUHN, W. 1973: Flämische und fränkische Hufe als Leitformen der Mittelalterlichen Ostsiedlung. In: Kuhn, W. (Ed.): Vergleichende Untersuchungen zur mittelalterlichen Ostsiedlung. Ostmitteleuropa in Vergengenheit und Gegenwart 16. Köln, 1-53.

LIENAU, C., UHLIG, H. (Eds.): 1978. Flur und Flurformen. Materialen zur Terminologie der Agrarlandschaft. Vol. I., 2. Auflage, Giessen.

LIMPERT, E., STAHEL, W. A., ABBT, M. 2001: Log-normal Distributions across the Sciences: Keys and Clues. BioScience 51, 341-352.

NIELSEN, N. H., KRISTIANSEN, S. M. 2014: Identifying ancient manuring: traditional phosphate vs. multi-element analysis of archaeological soil. Journal of Archaeological Science 42, 390-398.

NOVÁČEK, K. 1995: Zaniklé náhorní osídlení na Jinecku. Abandoned medieval settlement in the Jince region. Podbrdsko 2, 7-37.

PETRÁŇ, J. 1964: Poddaný lid v Čechách na prahu trucetileté války. The serf people in Bohemia at the beginning of the Thirty Years' War. Praha.

PROFOUS, A. 1951: Místní jména v Čechách. Jejich vznik, původ, význam a zmény III. The toponyms of Bohemia. Their origins, meaning and changes III. Praha.

R Core Team 2014: R: A language and environment for statistical computing. R Foundation for Statistical Computing, Vienna. URL http:// www.R-project.org/.

RBM VI - Regesta Diplomatica Nec Non Epistolaria Bohemiae et Moraviae Pars VI (1355-1363), Fasciculus I. Mendl, B. (Ed.), Pragae 1928. The Regesta of the deeds from Bohemia and Moravia. Available also online: http://147.231.53.91/src/index.php?s $=$ v\&cat=8\&bookid=698 (cited $8^{\text {th }}$ December 2015).

REIMANN, C., FILZMOSER, P. 2000: Normal and lognormal data distribution in geochemistry: death of a myth. Consequences for statistical treatment of geochemical and environmental data. Environmental Geology 39, 1001-1014.

REIMANN, C., FILZMOSER, P., GARRETT, R. G. 2005: Background and threshold: critical comparison of methods of determination. Science of the Total Environment 346, 1-16.

REIMANN, C., FILZMOSER, P., GARRETT, R., DUTTER, R. 2008: Statistical Data Analysis Explained. Applied Environmental Statistics with R. John Wiley and Sons.

REIMANN, C., FILZMOSER, P., FABIAN, K., HRON, K., BIRKE, M., DEMETRIADES, A., DINELli, E., LADENBERGER, A., and the GEMAS Project Team 2012: The concept of compositional data analysis in practice - Total major element concentrations in agricultural and grazing land soils of Europe. Science of the Total Environment 426, 196-210.

REIMANN, C., GARRETT, R. G. 2005: Geochemical background concept and reality. Science of the Total Environment 350, 12-27.

ROOS, C. I., NOLAN, K. C. 2012: Phosphates, plowzones, and plazas: a minimally invasive approach to settlement structure of plowed village sites. Journal of Archaeological Science 39, 23-32.

SALISBURY, R. B. 2013: Interpolating geochemical patterning of activity zones at Late Neolithic and Early Copper Age settlements in eastern Hungary. Journal of Archaeological Science 40, 926-934.

SCHOLKMANN, B., FROMMER, S., VOSSLER, Ch., WOLF, M. (Eds.) 2009: Zwischen Tradition und Wandel. Archäologie des 15. und 16. Jahrhunderts. Tübinger Forschungen zur historischen Archäologie 3. Tübingen.

SCHREG, R., 2013. Commons, cooperatives and village communes geographical and archaeological perspectives on the role of rural lower classes in settlement restructuring on the Swabian Alb Plateau. In: Klápště, J. (Ed.): Hierarchies in rural settlements. Ruralia IX. Brepols, Turnhout, 101-121.

SCHREG, R. 2014: Ecological Approaches in Medieval Rural Archaeology. European Journal of Archaeology 17/1, 83-119.

SCHRÖDER, K. H., SCHWARZ, G. 1969: Die ländlichen Siedlungsformen in Mitteleuropa. Grundzüge und Probleme ihrer Entwicklung. Forschungen zur Deutschen Landeskunde 175. Bad Godesberg.

SEDLÁČEK, A. 1923: Hrady, zámky a tvrze království českého XIV. The castles and strongholds of the Bohemian kingdom XIV. Praha. 
SMETÁNKA, Z. 1988: Život středověké vesnice. Zaniklá Svidna. Památníky naší minulosti 13. The life of a medieval village. The abandoned village of Svídna. The monuments of our history 13. Praha.

SMETÁNKA， Z., KLÁPŠTĚ, J. 1981: Geodeticko-topografický průzkum zaniklých středověkých vsí na Černokostelecku. Geodeticaltopographical survey of deserted medieval villages in the Kostelec nad Černými Lesy region. Památky archeologické 73, 416-458.

SMETÁNKA, Z., KLÁPŠTĚ, J., RICHTEROVÁ, J. 1979: Geodetickotopografický průzkum zaniklé středověké vesnice Ostrov (k. ú Jedomělice). Geodetical-topographical survey of a deserted medieval village Ostrov. Archeologické rozhledy 31, 420-430.

SOLLITO, D., ROMIC, M., CASTRIGNANÒ, A., ROMIC, D., BAKIC, H 2010: Assessing heavy metal contamination in soils of the Zagreb region (Northwest Croatia) using multivariate analysis. Catena 80, 182-194.

SOUČKOVÁ, K., HEJCMAN, M., KLÍR, T. 2013: Medieval Farming Practices in Deserted Villages Can be Determined Based on the Nitrogen Isotopic Signature in Recent Forest Soils. Interdisciplinaria Archaeologica - Natural Sciences in Archaeology IV/1/2013, 63-71.

ŠMEJDA, L., HEJCMAN, M., HORÁK, J., SHAI, I. 2017: Ancient settlement activities as important sources of nutrients $(\mathrm{P}, \mathrm{K}, \mathrm{S}, \mathrm{Zn}$ and $\mathrm{Cu})$ in Eastern Mediterranean ecosystems - The case of biblical Tel Burna, Israel. Catena 156. 63-72.

THOEN, E. 2004: "Social Agrosystems" as an Economic Concept to Explain Regional Differences. In: van Bavel, J. P., Hoppenbrouwers, P. (Eds.): Landholding and land transfer in the North Sea area (late Middle Ages $-19^{\text {th }}$ century). Turnhout, 47-66.
TOLASZ, R. et al. 2007: Climate atlas of Czechia. Praha-Olomouc.

VAŘEKA, P., AUBRECHTOVÁ, A., HNÍZDILOVÁ, P., NOVÁK, R., ROŽMBERSKÝ, P., VESELÁ, R. 2006: Archeologie zaniklých středověkých vesnic na Rokycansku 1. Archaeology of Deserted Medieval Villages in the Rokycany Region (West Bohemia) 1. Plzeň.

VERON, A., NOVÁK, M., BŘÍZOVÁ, E., ŠTĚPÁNOVÁ, M. 2014: Environmental imprints of climate changes and anthropogenic activities in the Ore Mountains of Bohemia (Central Europe) since 13 cal. kyr BP. The Holocene 24, 919-931.

WALKINGTON, H. 2010: Soil science applications in archaeological context: A review of key challenges. Earth-Science Reviews 103, 122 134.

WILSON, C. A., DAVIDSON, D. A., CRESSER, M. S. 2005: An evaluation of multielement analysis of historic soil contamination to differentiate space use and former function in and around abandoned farms. The Holocene 15, 1094-1099.

WILSON, C. A., DAVIDSON, D. A., CRESSER, M. S. 2008: Multi-element soil analysis: an assessment of its potential as an aid to archaeological interpretation. Journal of Archaeological Science 35, 412-424.

WILSON, C. A., DAVIDSON, D. A., CRESSER, M. S. 2009: An evaluation of the site specificity of soil elemental signatures for identifying and interpreting former functional areas. Journal of Archaeological Science 36, 2327-2334 
